\title{
Development and validation of a rapid high performance liquid chromatography - photodiode array detection method for estimation of a bioactive compound wedelolactone in extracts of Eclipta alba
}

\author{
Satyanshu Kumar*, Tushar Dhanani \\ Directorate of Medicinal and Aromatic Plants Research Boriavi, Anand, Gujarat, India
}

\begin{abstract}
Following optimization of extraction, separation and analytical conditions, a rapid, sensitive and simple reverse-phase high performance liquid chromatography-photo diode array (HPLC-PDA) method has been developed for the identification and quantification of wedelolactone in different extracts of Eclipta alba. The separation of wedelolactone was achieved on a $\mathrm{C}_{18}$ column using the solvent system consisting of a mixture of methanol: water: acetic acid (95: 5: 0.04) as a mobile phase in isocratic elution mode followed by photo diode array detection at $352 \mathrm{~nm}$. The developed method was validated as per the guidelines of the International Conference on Harmonization (ICH). Calibration curve presented good linear regression $\left(r^{2}>0.998\right)$ within the test range and the maximum relative standard deviation (RSD, \%) values for intra-day assay were found to be $0.15,1.30$ and 1.1 for low $(5 \mu \mathrm{g} / \mathrm{mL})$, medium $(20 \mu \mathrm{g} / \mathrm{mL})$ and high $(80 \mu \mathrm{g} / \mathrm{mL})$ concentrations of wedelolactone. For inter-day assay the maximum RSD (\%) values were found to be $2.83,1.51$ and 2.06 for low, medium and high concentrations, respectively. Limit of detection (LOD) and limit of quantification (LOQ) were calculated to be 2 and $5 \mu \mathrm{g} / \mathrm{mL}$ respectively. Analytical recovery of wedelolactone was greater than $95 \%$. Wedelolactone in different extracts of Eclipta alba was identified and quantified using the developed HPLC method. The validated HPLC method allowed precise quantitative analysis of wedelolactone in Eclipta. alba extracts.
\end{abstract}

Uniterms: High performance liquid chromatography/quantitative analysis. High performance liquid chromatography/photo diode array/method validation. Eclipta alba/extracts/analysis. Wedelolactone/ quantification.

Desenvolveu-se método rápido, sensível e simples de Cromatografia Líquida de Alta Eficiência em fase reversa, utilizando-se arranjo de fotodiodo (HPLC-PDA), visando à separação, extração e às condições analíticas para a identificação e quantificação de wedelolactona em diferentes extratos de Eclipta alba. A separação de wedelolactona foi efetuada por meio de uma coluna $\mathrm{C} 18$, utilizando mistura de metanol:água:ácido acético (95:5:0.04) como fase móvel, em sistema de eluição isocrática, seguida de detecção por arranjo de fotodiodo a $352 \mathrm{~nm}$. O método desenvolvido foi validado de acordo com as diretrizes da Conferência Internacional de Harmonização (ICH). As curvas de calibração apresentaram boa regressão linear $\left(r^{2}>0,998\right)$, dentro dos intervalos de teste, e os valores máximos de desvio padrão relativo (RSD,\%) dos ensaios intra-dia foram $0,15,1,30$ e 1,1 para concentrações de wedelolactona baixa $(5 \mu \mathrm{g} / \mathrm{mL})$, média $(20 \mu \mathrm{g} / \mathrm{mL})$ e elevada $(80 \mu \mathrm{g} / \mathrm{mL})$ Para o ensaio inter-dia,os máximos de RSD (\%) foram 2,83, 1,51 e 2,06 para as concentrações baixa, média e alta, respectivamente. O Limite de Detecção (LD) e o Limite de Quantificação (LOQ) foram de 2 e $5 \mu \mathrm{g} / \mathrm{mL}$, respectivamente. A recuperação analítica de wedelolactona foi maior do que 95\%. A wedelolactona em diferentes extratos de Eclipta alba foi identificada e quantificada pelo método de HPLC desenvolvido. O método de HPLC validado permitiu a análise quantitativa precisa de wedelolactona em extratos de Eclipta alba.

Unitermos: Cromatografia líquida de alta eficiência/análise quantitativa. Cromatografia líquida de alta eficiência/em fase reversa/validação de método. Eclipta alba/extratos/análise. Wedelolactona/ quantificação.

\footnotetext{
*Correspondence: Satyanshu Kumar. Directorate of Medicinal and Aromatic Plants Research Boriavi, Anand-378310, Gujarat, India. E-mail: satyanshu66@gmail.com
} 


\section{INTRODUCTION}

Eclipta alba (L.) Hassk. Syn. E. erecta L. "bhringaraja" belonging to the family of Asteraceae, is a small, branched annual herb with white flower heads. The plant grows abundantly as weed in cool, moist places throughout India (Chopra et al., 1956; Rastogi, Mehrotra, 1991). In Ayurvedic system of medicine, this plant is described as the best drug for treatment of liver cirrhosis and infective hepatitis. The plant juice is applied locally to treat finger decay caused due to infection during rainy season and extract is given in chronic fever. Leaf juice with buttermilk is used as antidote for snakebite. Shoot juice of E. alba mixed in equal amount with shoot juice of Oxalis corniculata Linn. is used as drops in injured eyes. The decoction of the plant is given for headache. The herb is reported to exhibit immuno-stimulatory activity and aqueous extract possessed myocardial depressant and hypotensive effect, unrelated to cholinergic acid and histaminergic effect in experimental animals. Coumestans, polypeptides, polyacetylenes, thiophene derivatives, steroids, triterpenes, and flavonoids have been reported as the main constituents of E. alba (Sarg et al., 1981). $\beta$-Amyrin, wedelolactone and luetolin 7-O-glucoside have been isolated from the aerial parts of the plant (Sikoria et al., 1982). Hentricontanol, 14-heptacosanol and stigmasterol have been reported from the roots of the plant (Singh et al., 1985). The coumestan, wedelolactone (Figure 1), is the bioactive principle of aerial parts of E. alba. Various biological activities such as hepatoprotective, antiplasmodial, sedative, anxiolytic, nootropic and anti-stress have been reported for wedelolactone (Saxena et al., 1993; Simonsen et al., 2001; Thakur et al., 2005). Wedelolactone exhibited activity as an antidote to snake venom (Bothrops jararaca). Albino mice (20 g average weight) were given a dose of $100 \mathrm{mg} / \mathrm{kg}$ of wedelolactone isolated from Eclipta prostrata by oral administration of one hour prior to envenomation. Ninety percent albino mice survived after six hours of envenomation and after 24 and 48 hours of being envenomed, forty percent survival was reported (Pereira et al., 1994). Although, chemical synthesis of wedelolactone has been reported by several groups (Chang et al., 2008), there are only few high performance liquid chromatography method for identification and quantification for wedelolactone in extracts of $E$. alba. Furthermore, reported methods are time consuming with analysis time varying from 30-40 minutes (Murali et al., 2002; Wagner et al., 1986) and not validated as per ICH guidelines. Therefore, present investigation was undertaken to develop a rapid, sensitive high performance liquid chromatography method for identification and quantification of wedelolactone in extracts of $E$. alba.

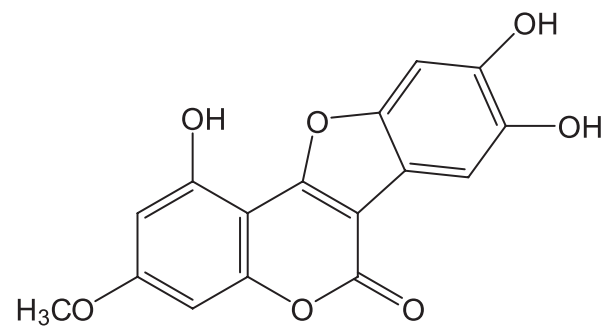

FIGURE 1 - Chemical structure of wedelolactone.

\section{MATERIAL AND METHODS}

\section{Material and Chemicals}

Whole plant of E. alba was collected from the experimental field of Directorate of Medicinal and Aromatic Plants Research, Boriavi, Anand in 2010. HPLC grade acetonitrile, methanol and water (Merck, Mumbai, India) were used. Standard wedelolactone purchased from Sigma-Aldrich was used for identification of peak and preparation of calibration curve.

\section{Instrumentation}

The HPLC system consisted of a Waters 600 E pump (Milford, MA, USA) equipped with quaternary solvent delivery system, 2996 photodiode array detector. Instrument control and data processing were performed using Empower software. The chromatographic separation was achieved using a SunFire ${ }^{\mathrm{TM}} \mathrm{C}_{18}$ column $(4.6 \times 150 \mathrm{~mm}$ packed with $5 \mu \mathrm{m}$ particle size; Waters, USA) at $25^{\circ} \mathrm{C}$.

\section{Methodology}

\section{Preparation of extract samples}

Whole plant of $E$. alba was dried in shade. Dried plant was finely powdered using an electric grinder and used for preparation of the extract. Powdered sample was extracted with methanol $(250 \mathrm{~mL} \mathrm{X} 6)$ for $24 \mathrm{~h}$ at $25^{\circ} \mathrm{C}$. The methanol extracts thus obtained were pooled together and concentrated under reduced pressure to obtain methanolic extract. Methanolic extract was suspended in water $(200 \mathrm{~mL})$ and fractionated with hexane $(100 \mathrm{~mL} \times 6)$, chloroform $(100 \mathrm{~mL} \times 6)$, ethyl acetate $(100 \mathrm{~mL} \times 6)$ and $n$-butanol $(100 \mathrm{~mL} \times 6)$ successively. The hexane extracts obtained were combined together, dried over anhydrous sodium sulfate and concentrated under reduced pressure to a residue of hexane extract. Similar processing of chloroform, ethyl acetate and $n$-butanol extracts provided their concentrated extracts, respectively. These concentrated extracts were further vacuum dried to remove traces of solvents. 


\section{Preparation of standard solution}

The standard stock solution $(1000 \mu \mathrm{g} / \mathrm{mL})$ of wedelolactone was prepared in HPLC grade methanol and stored at $4{ }^{\circ} \mathrm{C}$. Working solutions of lower concentrations were prepared by appropriate dilution of the stock solution in methanol. Stock solutions of different extracts of $E$. alba were prepared by dissolving $1 \mathrm{mg}$ of the extract in $1 \mathrm{~mL}$ methanol and filtered through a $0.45 \mu \mathrm{m}$ membrane filter.

\section{HPLC analysis}

To obtain HPLC chromatogram with good resolution and short analysis time per run, the chromatographic conditions were optimized, including the mobile phase and flow rate. The mobile phase was filtered through 0.45 $\mu \mathrm{m}$ membrane filter in solvent filtration apparatus (Millipore, USA). The solvents were degassed using vacuum before use. Several reverse phase HPLC columns were explored for the optimal separation including Symmetry $\mathrm{C}_{18}(250 \times 4.6 \mathrm{~mm}, 5 \mu \mathrm{m}), \mathrm{X}$ Terra $(250 \times 4.6 \mathrm{~mm}, 5 \mu \mathrm{m})$ and SunFire $(4.6 \times 150 \mathrm{~mm}, 5 \mu \mathrm{m})$ (Waters, Milford, MA, USA) and Lichro CART ${ }^{\mathrm{R}} 250-4 \mathrm{C}_{18}$ column $(250 \times 4.6 \mathrm{~mm}$ packed with $5 \mu \mathrm{m}$ particle size) (Merck, Germany). However, the best chromatographic separation was achieved using Sunfire ${ }^{\mathrm{TM}} \mathrm{C}_{18}$ column at $25^{\circ} \mathrm{C}$. Both acetonitrilewater and water-methanol were tested as the mobile phase system under isocratic as well as gradient elution mode. However, methanol-water-acetic acid (95: 5: 0.04) as mobile phase in isocratic elution with a flow rate $0.6 \mathrm{~mL} / \mathrm{min}$ provided better peak shape and resolution. Analysis was performed with a total runtime of $10 \mathrm{~min}$. Detector wavelength was $352 \mathrm{~nm}$ and the injection volume was $10 \mu \mathrm{L}$. At this wavelength, wedelolactone has adequate absorption according to its three-dimensional ultraviolet absorption spectra. Mean retention time was 2.9 min (Table I). A chromatogram of standard wedelolactone has been shown in Figure 2.

TABLE I - Method validation data for determination of wedelolactone

\begin{tabular}{lc}
\hline Data & Value \\
\hline Mean retention time & $2.89 \min (\mathrm{RSD} \mathrm{0.7 \% )}$ \\
Linear range & $5-100 \mu \mathrm{g} / \mathrm{mL}$ \\
Regression coefficient & 0.998 \\
Limit of detection (LOD) & $2 \mu \mathrm{g} / \mathrm{mL}$ \\
Limit of quantification (LOQ) & $5 \mu \mathrm{g} / \mathrm{mL}$ \\
\hline
\end{tabular}

\section{RESULTS AND DISSCUSSION}

\section{Validation of the HPLC method}

Linearity

As the linear range of analytical method is known to be limited, linearity of the calibration curve prepared and its working range was determined. Determination of linearity was based on detector response of the different concentrations of standard used for calibration curve. Regression analysis was used to access the linearity of the developed HPLC method using the equation, $\mathrm{y}=\mathrm{bx}+\mathrm{c}$, where, $\mathrm{x}$ correspond to the concentration of the standard solution $(\mu \mathrm{g} / \mathrm{mL}), y$ is the peak area, $\mathrm{b}$ is slope of the line,

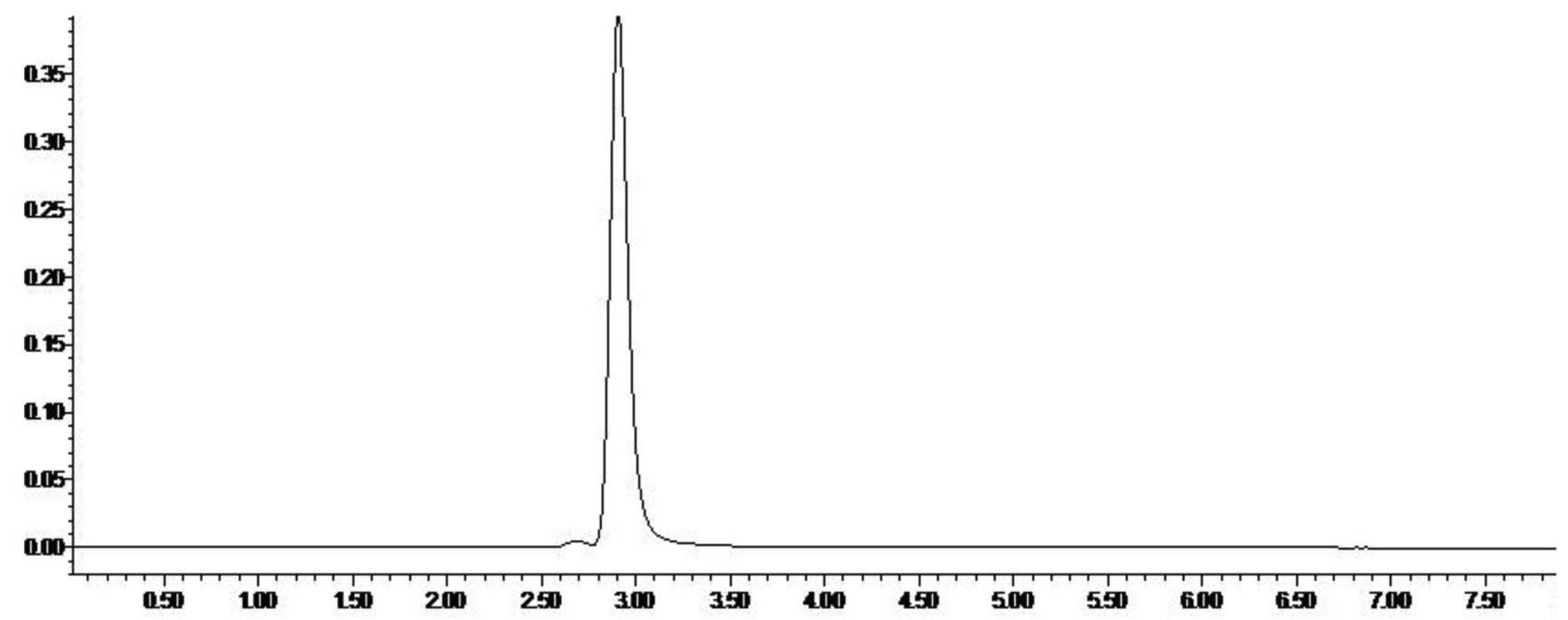

FIGURE 2 - HPLC-PDA chromatogram of standard wedelolactone (concentration=20 ppm) at 352 nm, mobile phase consisting of methanol: water: acetic acid $(95: 5.0: 0.04)$ on Sunfire $(4.6 \times 150 \mathrm{~mm}, 5 \mu \mathrm{m})$ column at a flow rate of $0.6 \mathrm{~mL} / \mathrm{min}$. 
and $\mathrm{c}$ is intercept of the straight line with y axis. In the present study, linearity was studied in the concentration range of $5-100 \mu \mathrm{g} / \mathrm{mL}$ of the standard solution of wedelolactone (Table I). The calibration curve was linear in this concentration range and showed good linear regression $(\mathrm{Y}$ $\left.=86558 \mathrm{x}-125096, \mathrm{r}^{2}=0.998\right)$.

\section{Limit of detection (LOD) and limit of quantification (LOQ)}

Lowest concentration of analyte detectable and quantifiable with a stated degree of reliability is one of the many important parameters of any analytical method. Limit of detection (LOD), signal to noise ratio $(\mathrm{S} / \mathrm{N})=3$ or above is the lowest amount of analyte in a sample that can be detected but not necessarily quantified. Limit of quantification (LOQ) is defined as the lowest concentration, which can be reproducibly quantified above baseline level, typically for LOQ, S/N = 10 or above. The LOD and LOQ for the present HPLC method developed were measured as per guidelines described by the International Conference on Harmonization (ICH, 1996). LOD and LOQ as determined were found to be 2 and $5 \mu \mathrm{g} / \mathrm{mL}$ respectively (Table I).

\section{Precision}

Intraday precision (repeatability) was evaluated for three concentrations (low, medium and high) of standard with duplicate injections during the same day, under the same experimental conditions. Inter day precision was also measured for the same three concentrations during three different days. Intraday precision of the analyte was in the range of $0.15-1.1 \%$ and the inter day precision varied from $2.06-2.83 \%$ (Table II). The specificity of the method was examined by analyzing blank sample and blank sample spiked with a known concentration of wedelolactone. No interference in the retention time of the analyte was observed.

TABLE II - Accuracy and precision (R.S.D.) of the method developed at three different concentrations

\begin{tabular}{lccc}
\hline \multirow{2}{*}{ Analyte } & \multicolumn{2}{c}{ Concentration $(\mu \mathrm{g} / \mathrm{mL})$} & \multirow{2}{*}{$\mathrm{RSD}(\%)$} \\
\cline { 2 - 3 } & Intra-day & Inter-day & \\
\hline \multirow{3}{*}{ Wedelolactone } & 5 (Low) & .15 & 2.83 \\
& 20 (Medium) & 1.31 & 1.51 \\
& 80 (High) & 1.1 & 2.06 \\
\hline
\end{tabular}

Accuracy

The accuracy of an analytical method is the closeness of test results obtained by that method to the true value and was determined based on the recovery of known amounts of analyte. Analytical recovery was performed by analyzing analyte by spiking $60 \mu \mathrm{g} / \mathrm{mL}$ of the standards in blank extract (aqueous extract) for six different days. The recovery ranged from 95.80 to $101.76 \%$.

\section{Application to the identification and quantification of wedelolactone in different extracts of $E$. Alba}

For locating the best fraction enriched with wedelolactone, methanol extract was further fractionated using solvents of varying polarity to get hexane, chloroform, ethyl acetate and n-butanol extracts. Thereafter, the developed HPLC method was applied to determine the concentration of wedelolactone in different extracts. Peak of wedelolactone in different extracts was identified on the basis of retention time of standard wedelolactone (Figure 3-7). From the chromatograms of different extracts, it was concluded that as the polarity of solvent used for liquid-liquid fractionation increased the extracts were purified and the area of additional peaks decreased. Many additional peaks were recorded in HPLC chromatogram of hexane extract, however, no additional peak was observed in n-butanol extract. Quantity of wedelolactone in different extracts was calculated from the peak area of HPLC chromatograms of the extracts and its content in different extracts has been summarized in Table III. This information could be utilized for development of up-scaling process.

TABLE III - Wedelolactone content (mean \pm S.D) in different extracts of $E$. alba

\begin{tabular}{lc}
\hline Extract & Wedelolactone (\%) \\
\hline Methanol & $6.62+0.93$ \\
Hexane & $0.80 \pm 0.03$ \\
Chloroform & $0.94 \pm 0.12$ \\
Ethyl acetate & $8.24 \pm 0.70$ \\
n-Butanol & $11.81 \pm 0.64$ \\
\hline
\end{tabular}

Solvent and method used for extraction affects the functional efficacy of medicinal plants extracts. Kulkarni et al. (2011), reported extraction of wedelolactone from E. alba using six different methods of extraction and its estimation by HPTLC. The highest percentage of wedelolactone was found in extract prepared by Soxhlet extraction and lowest in case of Supercritical fluid extraction; the yield difference was attributed to polar nature of wedelolactone. It has been reported that partitioning with polar solvents led to enrichment of wedelolactone 


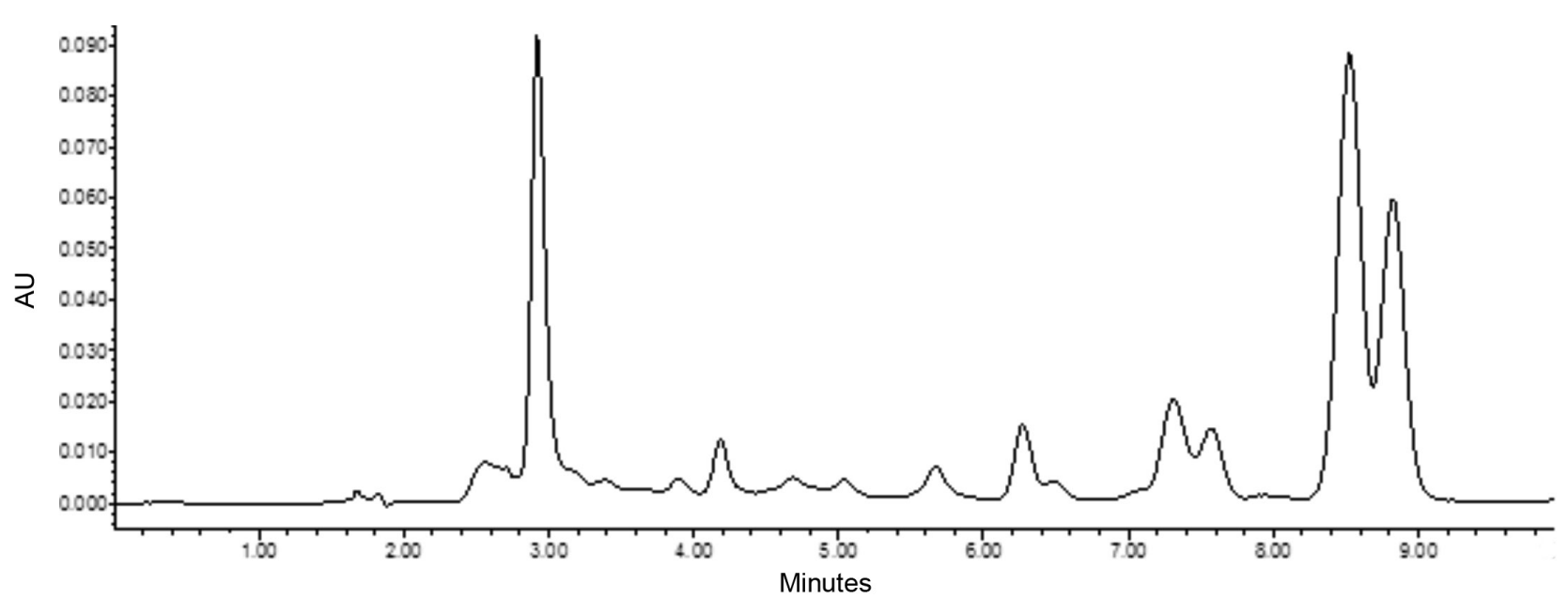

FIGURE 3 - HPLC-PDA chromatogram of methanol extract of E. alba.

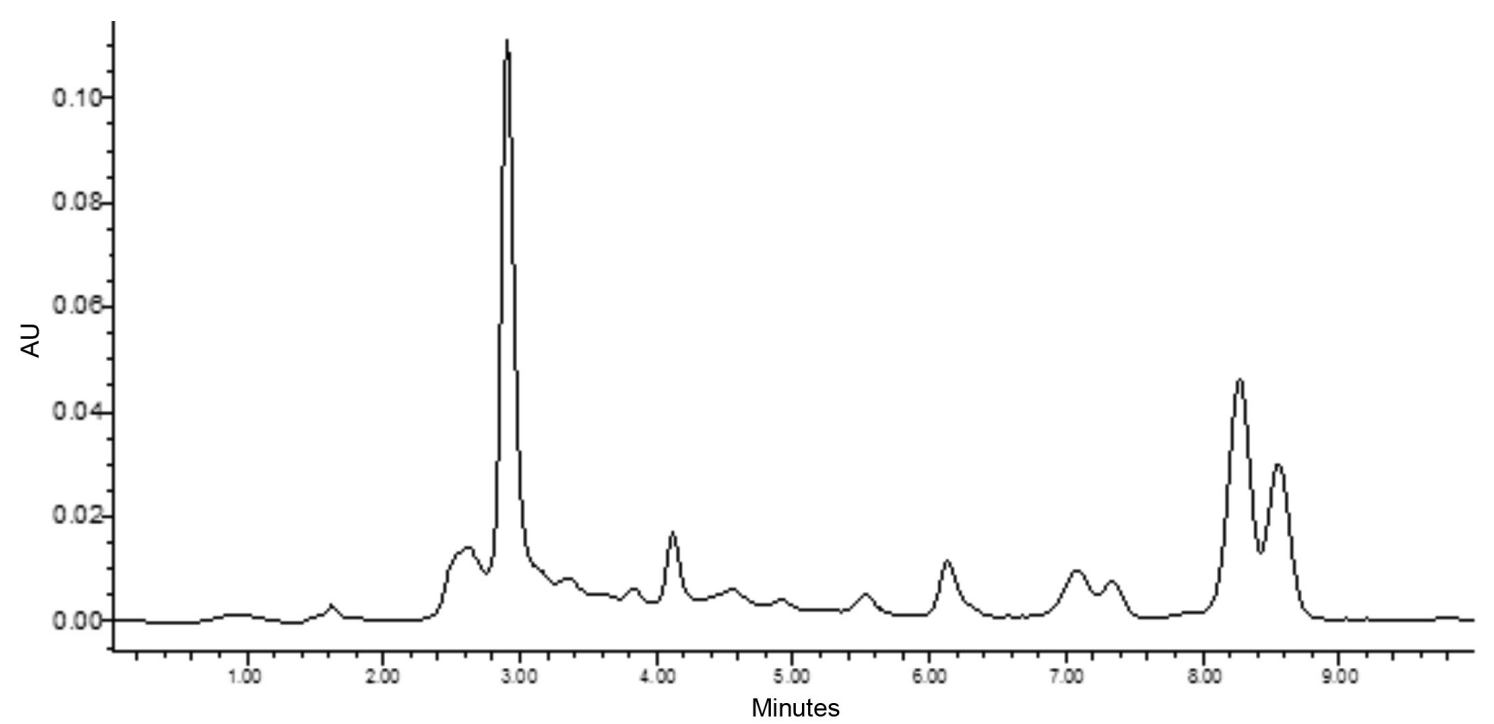

FIGURE 4 - HPLC-PDA chromatogram of hexane extract of E. alba.

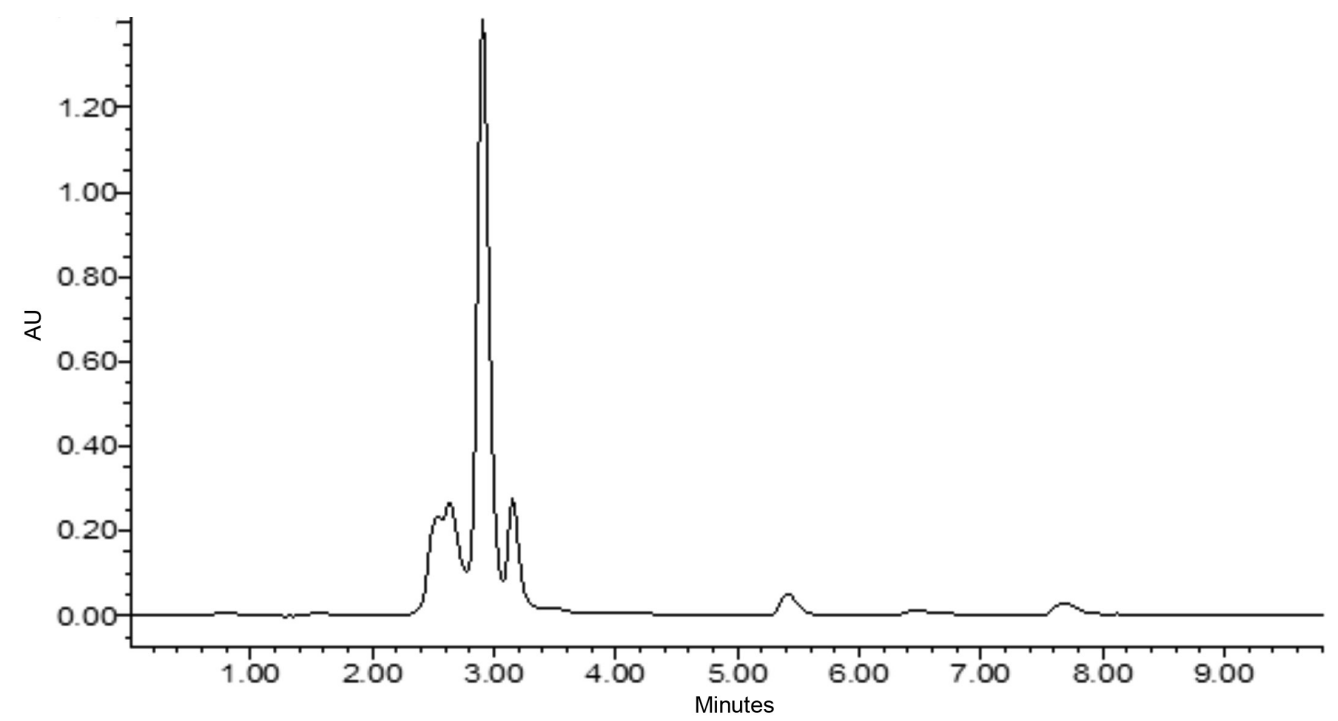

FIGURE 5 - HPLC-PDA chromatogram of chloroform extract of E. alba. 


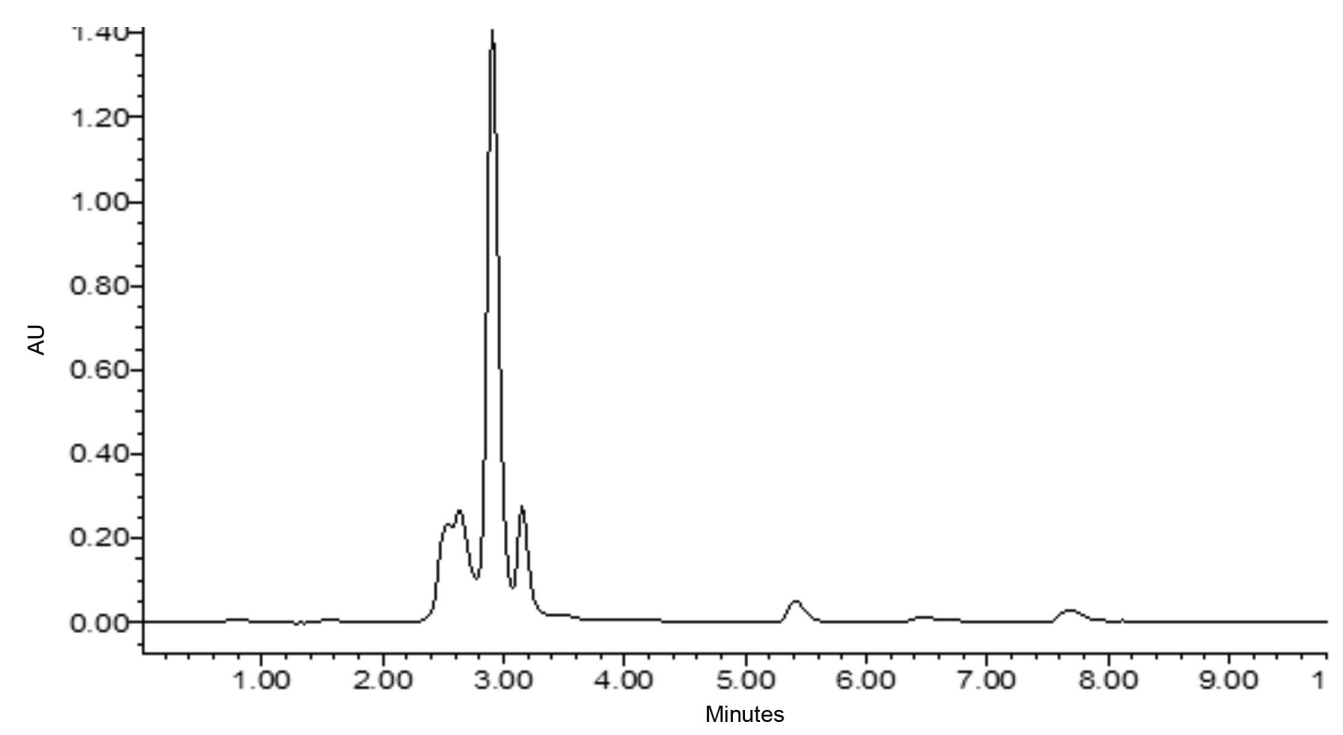

FIGURE 6 - HPLC-PDA chromatogram of ethyl acetate extract of E. alba.

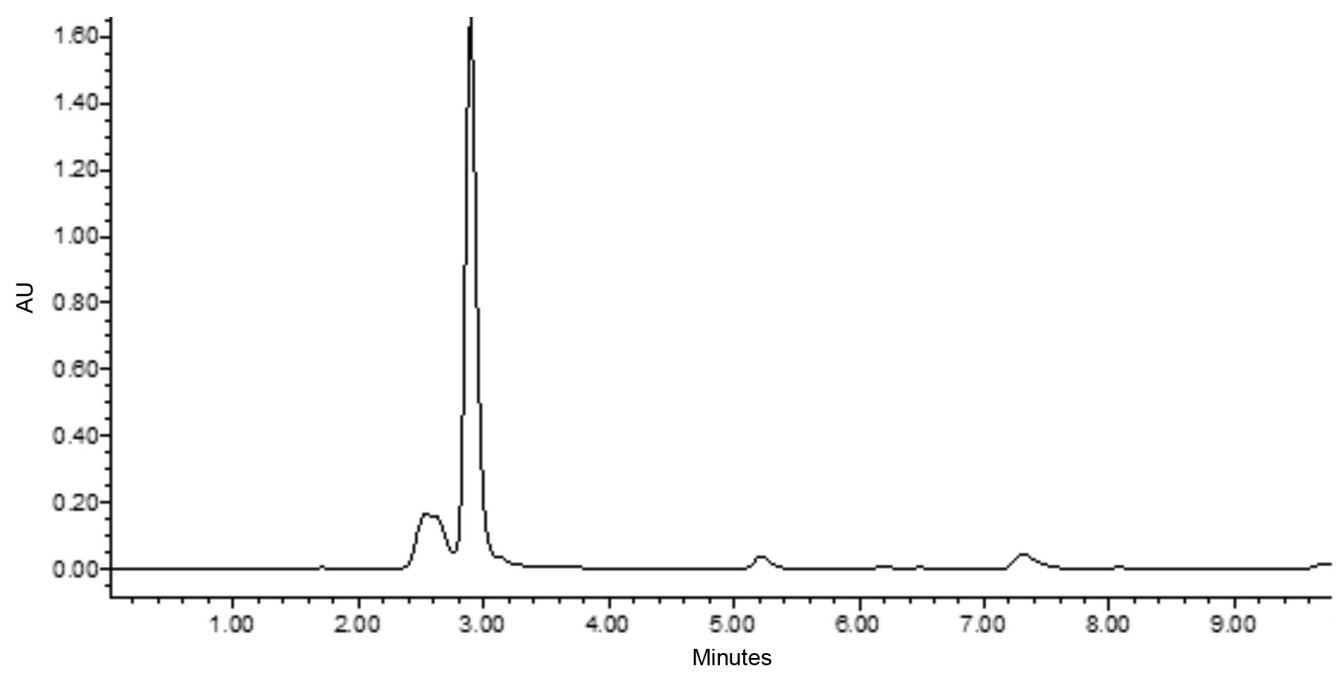

FIGURE 7 - HPLC-PDA chromatogram of n-butanol extract of E. alba.

in extract. Wagner et al. (1986) reported 1.6\% and 15.9\% wedelolactone in methanol and ethyl acetate extracts of $E$. alba respectively. In the present study, the butanol fraction has highest content of wedelolactone; we speculate that this fraction of $E$. alba may provide maximum bioactivity. Similar results have been reported by Kim et al., (2008). The earlier reported HPLC methods (Murali et al., 2002; Wagner et al., 1986) were not validated; we validated the developed method as per ICH guidelines. Further, use of acetic acid in place of phosphoric acid will enhance the longevity of HPLC column.

\section{CONCLUSION}

The validated HPLC method allows a simple, accurate and precise quantitative analysis of a biologically important molecule wedelolactone from E. Alba. Presence or absence of wedelolactone in different extracts of $E$. Alba, related species and commercial formulations can be confirmed by comparing their retention times $\left(\mathrm{t}_{\mathrm{R}}\right)$ using developed method. Moreover, maximum wedelolactone content was found in $n$-butanol extract followed by ethyl acetate extract, thus it appears that $n$-butanol or ethyl acetate would be a suitable solvent for partitioning of the methanol extract for isolation of wedelolactone from E. alba.

\section{ACKNOWLEDGEMENTS}

The authors are grateful to the director, DMAPR, Anand, for providing necessary facilities and encouragements. 


\section{REFERENCES}

CHANG, C.F.; CHANG, S.W.; FANG, Y.T.; YANG, L.Y.; LEE, Y.J. Total synthesis of demethylwedelolactone and wedelolactone by $\mathrm{Cu}$-mediated /Pd (O)-catalysis and oxidative cyclization. Tetrahedron, v.64, n.17, p.36613666, 2008.

CHOPRA, R.N.; CHOPRA, I.C.; NAYAR, S.L. Glossary of Indian medicinal plants. New Delhi: CSIR, 2008. $1041956 \mathrm{p}$.

INTERNATIONAL CONFERENCE ON HARMONIZATION. Technical requirements for registration of pharmaceuticals for human use: harmonized triplicate guidelines on validation of analytical procedures: methodology, recommended for adoption at step 4 of the ICH. Process on: Nov 1996. Process by: ICH steering committee, IFPMA. Switzerland, 1996.

KIM, D.; LEE, S.H.; CHOI, J.H.; LILLEHOJ, S.H.; YU, M.H.; LEE, G.S. The butanol fraction of Eclipta prostrata (Linn) effectively reduces serum lipid levels and improves antioxidant activities in CD rats. Nutr. Res., v.28, n.8, p.550554, 2008.

KULKARNI, S.; KHATWANI, P. Optimization of extraction conditions of a sensitive HPTLC method for estimation of wedelolactone in different extracts of Eclipta alba. IJPSDR., v.3, n.1, p.56-61, 2011.

MURALI, B.; AGRAWAL, A.; ANAND, M.S.; SAMIULLA, D.S. Estimation of wedelolactone and demethylwedelolactone in Eclipta alba Hassk by improved chromatographic analysis. J. Nat. Remedies, v.2, n.1, p.99101, 2002.

PEREIRA, N.A.; PEREIRA, B.M.R.; NASCIMENTO, M.C.; PARENTE, J.P; MORS, W.B. Pharmacological screening of plants recommended by folk medicine as snake venom antidotes; IV- protection against Jararaca venom by isolated constituents. Planta Med., v.60, n.2, p.99-100, 1994.
RASTOGI, R.P.; MEHROTRA, B.N. Compendium of Indian medicinal plants. v.2 New Delhi: CSIR, 1991. v.2, p.288.

SARG, T.M.; SALAM, N.A.A.; EL-DOMIATY, M.; KHAFAGY, S.M. The steroid, triterpenoid and flavonoid constituents of Eclipta alba (L.) Hassk. (compositae) grown in Egypt. Sci. Pharm., v.49, n.30, p.262-264, 1981.

SAXENA, A.K.; SINGH, B.; ANAND, K.K. Hepatoprotective effects of Eclipta alba on subcellular levels in rats. $J$. Ethnopharmacol., v.40, n.3, p.155-161, 1993.

SIKRORIA, B.C.; SRIVASTAVA, S.J.; NIRANJAN, G.S. Phytochemical studies on Eclipta alba. J. Indian Chem. Soc., v.59, n.7-12, p.905-909, 1982.

SIMONSEN, H.T.; NORDSKJOLD, J.B.; SMITT, U.W.; NYMAN, U.; PALPU, P.; JOSHI, P.; VERGESE, G. In vitro screening of Indian medicinal plants for antiplasmodial activity. J. Ethnopharmacol., v.74, n.2, p.195-204, 2001.

SINGH, P.; SHARMA, A.K.; JOSHI, K.C.; BOHLMANN, F. A further dithienylacetylene from Eclipta erecta. Phytochemistry, v.24, n.4, p.615-616,1985.

THAKUR, V.D., MENGI, S.A. Neuropharmacological profile of Eclipta alba (Linn.) Hassk. J. Ethnopharmacol., v.102, n.1, p.23-31, 2005.

WAGNER, H.; GEYER, B.; KISO, Y.; HIKINO, H.; RAO, G.S. Coumestans as the main active principles of the liver drugs Eclipta alba and Wedelia calendulacea. Planta Med., v.52, n.5, p.370-374, 1986.

Received for publication on $12^{\text {th }}$ April 2012 Accepted for publication on $02^{\text {nd }}$ November 2012 
